\title{
Sukcesja prawowitych dziedziców Pomorza Jana Dąbrówki. Studium źródłoznawcze i edycja krytyczna*
}

\begin{abstract}
Zarys treści: Treścią artykułu jest studium źródłoznawcze i edycja krytyczna Sukcesji prawowitych dziedziców Pomorza - dziełka Jana Dąbrówki uważanego wcześniej za dwa oddzielne utwory (zwane Genealogia ksiażat pomorskich oraz Pocztem książąt i królów polskich). Omówiono jedyny rękopis tego dzieła (znajdujący się w kodeksie BN 3002 III), a także czas jego powstania, osobę autora, źródła, treść ideową oraz cel. W aneksie zawarto edycję krytyczną.
\end{abstract}

\begin{abstract}
The article's content is a source study and critical edition of the short text Sukcesja prawowitych dziedziców Pomorza (Succession of Rightful Heirs of Pomerania) by Jan Dąbrówka, regarded earlier as two separate pieces (entitled Genealogia ksiażąt pomorskich [Genealogy of Pomeranian Princes] and Poczet ksiażąt i królów polskich [Gallery of Princes and Kings of Poland]). The article's author describes the only manuscript of this text (in the codex 3002 III preserved in the National Library in Warsaw), the time of its compilation, its author, sources, ideological content, and the purpose of its writing. The appendix contains the critical edition of the Succession.
\end{abstract}

Słowa kluczowe: Jan Dąbrówka, Sukcesja prawowitych dziedziców Pomorza, Genealogia książąt pomorskich, Poczet książą i królów polskich, Kronika oliwska, kodeks Jana Dąbrówki, wojna trzynastoletnia

Keywords: Jan Dąbrówka, Succession of Rightful Heirs of Pomerania, Genealogy of Pomeranian Princes, Gallery of Princes and Kings of Poland, Oliva Chronicle, manuscript of Jan Dąbrówka, Thirteen Years' War

Niniejszy artykuł stanowi studium źródłoznawcze i edycję krytyczną dziełka Jana Dąbrówki znajdującego się na obu stronach karty 316 w rękopisie Biblioteki Narodowej w Warszawie 3002 III (tzw. kodeks Jana Dąbrówki)ํ. Treścią zabytku jest genealogia władców Pomorza Gdańskiego z dynastii Sobiesławiców aż do Mściwoja II, a następnie lista polskich książąt i królów będących według autora ich prawowitymi dziedzicami, począwszy od księcia Przemysła I. Z tego powodu proponuję nadać dziełku tytuł erudycyjny Sukcesja prawowitych dziedziców Pomorza (w wersji łacińskiej: Successio legitimorum heredum Pomeraniae).

\footnotetext{
* Podstawowe tezy tej pracy zostały zaprezentowane $\mathrm{w}$ formie referatu na seminarium magisterskim dr. hab. Wojciecha Drelicharza, prof. UJ, w roku akademickimi 2016/2017. Dziękuję zarówno prowadzącemu seminarium, jak i uczestnikom za dyskusję i uwagi. Dziękuję również prof. dr hab. Beacie Możejko, dr. hab. Piotrowi Węcowskiemu oraz mgr Hannie Rajfurze za ogromną pomoc w dotarciu do literatury w okresie zamknięcia bibliotek podczas epidemii COVID-19.

${ }^{1}$ Dalej cyt. jako Kodeks Dąbrówki. Korzystałem z wersji online pochodzącej z Biblioteki Cyfrowej Polona, <https://polona. pl/item/miscellanea-historica,MjY0NjQ3/> [dostęp: 22.01.2020].
} 
Do tej pory literatura naukowa nie zauważyła istnienia Sukcesji jako jednego i spójnego dzieła. Uważano, że są to dwa mniejsze dziełka, jedno traktujące o książętach pomorskich, a drugie o władcach Polski ${ }^{2}$ Pierwszym, który tak potraktował Sukcesję, był August Bielowski w przypisach do edycji Rocznika wielkopolskiego ${ }^{3}$. W XX i XXI w. kolejni badacze podążali jego śladem ${ }^{4}$. Brygida Kürbis sporządziła zaś jedyną edycję krytyczną obu rzekomych zabytków, zawartą w przypisie do jej wydania Rocznika kapituly poznańskiej. . Ostatnio o licznych, a mało docenianych opera minora Jana Dąbrówki przypomniał Piotr Węcowski, wzmiankując również - jak napisał - Genealogię książąt pomorskich oraz Poczet książat $i$ królów polskich. Wyraził przypuszczenie, że pierwsze z tych dzieł mogło być związane z pracą Dąbrówki jako eksperta królewskiego w czasie rokowań polsko-krzyżackich, a drugie określił jako „silnie związane" z pierwszym ${ }^{6}$. To ostatnie spostrzeżenie było niewątpliwie krokiem w dobrym kierunku, niemniej P. Węcowski nie postawił kropki nad i - nie zdecydował się na łączne potraktowanie obu zabytków.

Mimo dotychczasowej tradycji historiograficznej, sądzę, że należy uznać Sukcesję prawowitych dziedziców Pomorza za jedno dzieło. Przemawia za tym jej treść, a także względy paleograficzne i kodykologiczne, jak również fakt wykorzystywania jednego źródła (Kroniki oliwskiej) w obu częściach utworu. Poza tym Sukcesja jest logicznym wywodem praw króla Kazimierza Jagiellończyka do Pomorza Gdańskiego. Jej treść ideowa i cel powstania są jasne, co postaram się udowodnić w dalszej części artykułu. Jeśli zaś uznajemy istnienie dwóch oddzielnych utworów zamiast jednego, ich cel powstania jest zagadkowy i niejasny, zwłaszcza Pocztu książat i królów polskich.

Jak już wzmiankowałem, Sukcesja prawowitych dziedziców Pomorza znana jest z jednego rękopisu. Zawierający ją kodeks jest nazywany w literaturze kodeksem Jana (z) Dąbrówki lub kodeksem lubińskim. Był on już wielokrotnie opisywany w literaturze ${ }^{7}$, najdokładniej przez Mariana Zwiercana ${ }^{8}$. Ograniczę się tylko do ogólnego przeglądu zawartości i przyjrzenia się najbliższemu otoczeniu Sukcesji, korzystając z opisu M. Zwiercana i na podstawie obserwacji własnych.

Kodeks Jana Dąbrówki to papierowy rękopis o wymiarach 22 na $31 \mathrm{~cm}$, złożony z 356 numerowanych kart XV-wiecznych i 4 kart ochronnych dodanych w XIX w. Oprawa pochodzi z pierwszej połowy XIX w. M. Zwiercan podzielił kodeks na dwie części pod względem zawartości i budowy. Pierwsza obejmuje k. 1-35. Najistotniejsze dzieła w niej zawarte to Kronika Dzierzwy oraz Rocznik małopolski Jana Dąbrówki. Następną część tworzą dwa elementy. Pierwszy (k. 36-266) zawiera Kronikę mistrza Wincentego wraz z brulionem komentarza do niej autorstwa Dąbrówki. Kolejne karty (267-356) zajmują (z kilkoma wyjątkami) dzieła historiograficzne wchodzące w skład kolekcji historycznej zwanej Kronika wielka, a więc m.in. Kronika wielkopolska, Kronika Janka z Czarnkowa, Rocznik kapituly poznańskiej. Kodeks powstał w latach 30. XV w. w związku z tworzeniem przez Jana Dąbrówkę komentarza do Kroniki mistrza Wincentego. Większość dzieł wpisano do kodeksu w tym właśnie okresie, jednak pewne zabytki zostały dodane na pozostawionych wcześniej wolnych kartach. Sukcesja należała do tekstów dopisanych później.

\footnotetext{
${ }^{2}$ Zdarzały się też mniej precyzyjne próby określenia, czym jest Sukcesja, zob. np. J. Korzeniowski, Zapiski z rękopisów Cesarskiej Biblioteki Publicznej w Petersburgu i innych bibliotek petersburskich. Sprawozdanie z podróży naukowych odbytych w 1891-1892 i 1907 r., Kraków 1910, s. 84; Katalog wystawy zbiorów historycznych w Bibliotece Narodowej w Warszawie, Warszawa 1933, nr 129, s. 50.

3 Rocznik wielkopolski, wyd. A. Bielowski, w: MPH, t. 3, Lwów 1878, s. 39, przyp. 1.

${ }^{4}$ W kolejności chronologicznej: B. Kürbis, Studia nad Kronika wielkopolska, Poznań 1952, s. 46; taż, Wstęp, w: Roczniki wielkopolskie, wyd. B. Kürbis, współudz. G. Labuda, J. Luciński, R. Walczak, w: MPH s.n., t. 6, Warszawa 1962, s. XXV; J. Wiesiołowski, Kolekcje historyczne w Polsce średniowiecznej XIV-XV w., Wrocław 1967, s. 54; M. Zwiercan, Komentarz Jana z Dąbrówki do Kroniki mistrza Wincentego zwanego Kadlubkiem, Wrocław 1969, s. 16; W. Drelicharz, Annalistyka małopolska XIII-XV wieku. Kierunki rozwoju wielkich roczników kompilowanych, RAU whf, t. 99, Kraków 2003, s. 66; Inwentarz rękopisów do połowy XVI wieku w zbiorach Biblioteki Narodowej, oprac. J. Kaliszuk, S. Szyller, Inwentarze Rękopisów Biblioteki Narodowej, t. 3, Warszawa 2012, s. 69.

${ }_{5}^{5}$ Rocznik kapituly poznańskiej, w: Roczniki wielkopolskie, s. 52, przyp. *.

${ }^{6}$ P. Węcowski, ,Opera minora” Jana z Dąbrówki, w: Komentarz Jana z Dąbrówki do Kroniki biskupa Wincentego, red. A. Dąbrówka, M. Olszewski, Studia staropolskie. Series Nova, t. 42 (98), Warszawa 2015, s. 69 n.

${ }^{7}$ Najnowszy opis został zawarty w: Inwentarz rękopisów, s. 69 n., tam też wymienione poprzednie opisy.

${ }^{8}$ M. Zwiercan, Komentarz Jana z Dąbrówki, s. 12-20.
} 
Na k. 267r-316r znajduje się Kronika wielkopolska. Kończy się ona rozdziałem [164] w połowie wysokości k. 316r. Pod nim znalazła się pierwsza część Sukcesji prawowitych dziedziców Pomorza, informująca o dynastii Sobiesławiców. Około 2/3 następnej strony (k. 316v) zajmuje pozostała część Sukcesji. Reszta strony została pozostawiona pusta, poza słowami anno domini 1296, gdzie cyfra 6 została przekreślona, a obok dopisano cyfrę 5. Najpewniej miał być to początek notki, z której zrezygnowano. Kartę 317r zajmują notki [121]-[124] z Rocznika kapituty poznańskiej. Na k. 317v znajduje się z kolei wyciąg z Kroniki oliwskiej ${ }^{9}$. Na kartach od 318r aż do 321r zamieszczono Kronikę Janka z Czarnkowa. Sukcesja została wpisana do kodeksu - według oceny M. Zwiercana - ręką samego Jana Dąbrówki. Co więcej, taki sam kolor atramentu (ciemnobrązowy) oraz grubość końcówki pióra (większa niż zwykle) wskazują, że całą treść tego utworu wpisano jednocześnie.

Osoba autora Sukcesji nie budziła nigdy większej dyskusji. Za Janem Dąbrówką opowiedzieli się Marian Zwiercan ${ }^{10}$, Jacek Wiesiołowski ${ }^{11}$ oraz Piotr Węcowski ${ }^{12}$. Poza tym, jak już wspomniano, w kodeksie Dąbrówki już na następującej po Sukcesji karcie znajdują się wypisy z Kroniki oliwskiej. Wszystkie one były - według M. Zwiercana - zapisane ręką mistrza Jana. Dowodzi to, że miał on bezpośredni dostęp do Kroniki oliwskiej, co zmniejsza prawdopodobieństwo, że autorem Sukcesji był ktoś inny.

O czasie powstania Sukcesji wypowiadali się jedynie M. Zwiercan i P. Węcowski. Pierwszy stwierdził, że została wpisana do kodeksu zapewne w 1462 r. ${ }^{13}$ Drugi zaś ostrożnie datował ją na okres panowania Kazimierza Jagiellończyka, zapewne na lata $60 . \mathrm{XV}$ w. ${ }^{14}$

Tymczasem terminus post quem powstania Sukcesji możemy wyznaczyć nieco dokładniej. Nie mogła ona bowiem powstać, zanim w ręce jej autora nie dostało się najważniejsze źródło - Kronika oliwska. To z kolei nie mogło nastąpić wcześniej niż w ramach przygotowania do polsko-krzyżackich rozmów pokojowych w Toruniu, zapośredniczonych przez miasta hanzeatyckie w lipcu 1464 r. Jako członkowie zespołu królewskich ekspertów uczestniczyli w nich m.in. Jan Dąbrówka, Jan Długosz oraz Jakub z Szadka. 5 V 1464 wysłali oni list do Jana Lutkowica, biskupa włocławskiego, prosząc go, aby za jego pośrednictwem mieszczanie gdańscy i toruńscy wysłali im m.in. „cronicam, quam monasterium Olywa habet"15, aby mogli lepiej przygotować się do przedstawienia sprawy i do dyskusji z przeciwnikami. Kroniką wzmiankowaną w liście musiała być oczywiście Kronika oliwska. Prawie 2 tygodnie później, 18 maja, prośba nie była jeszcze spełniona i zaszła konieczność ponaglenia gdańszczan. Jeszcze 30 czerwca polscy posłowie upominali miasto Gdańsk w sprawie dosłania im pewnych materiałów, nie wymieniono jednak wśród nich Kroniki oliwskiej. Obrady polsko-krzyżackie rozpoczęły się wreszcie, po długich perypetiach, w Toruniu 3 VII 1464. Tego samego dnia Jan Dąbrówka wygłosił mowę, która nie zawiera jednak śladów znajomości faktów podanych w Sukcesji ${ }^{16}$. Już 21 lipca negocjacje zakończyły się odrzuceniem przez stronę polską propozycji krzyżackich. Wkrótce potem delegacja polska, zapewne wraz z Janem Dąbrówką, wróciła do Krakowa ${ }^{17}$.

Co możemy wywnioskować z takiego przebiegu zdarzeń? Z pewnością bezwzględnym terminus post quem daty pozyskania Kroniki oliwskiej przez Dąbrówkę jest maj 1464 r. Jeśli bowiem miałby do niej dostęp wcześniej, nie musiałby fatygować biskupa, mieszczan i cystersów z Oliwy. Czy jednak musiało to nastąpić po 30 czerwca tegoż roku? Niekoniecznie. Sławomir Zonenberg uznał, że Długosz

9 Wyd.: Roczniki wielkopolskie, s. 54, przyp. **.

${ }^{10}$ M. Zwiercan, Komentarz Jana z Dąbrówki, s. 16.

11 J. Wiesiołowski, Kolekcje historyczne, s. 54.

12 P. Węcowski, „Opera minora” Jana z Dąbrówki, s. 69 n.

13 M. Zwiercan, Komentarz Jana z Dąbrówki, s. 16.

${ }^{14}$ P. Węcowski, ,Opera minora” Jana z Dąbrówki, s. 69 n.

15 Cyt. za: Hanserecesse von 1431-1476, t. 5, wyd. G. von der Ropp, Leipzig 1888, nr 458, s. 385.

16 Tekst mowy: tamże, nr 444, s. 369-374.

17 O rokowaniach zob. M. Biskup, Trzynastoletnia wojna z Zakonem Krzyżackim 1454-1466, Olsztyn 2014, s. 663-671; tenże, Działalność dyplomatyczna Jana Dlugosza w sprawach pruskich w latach 1454-1466, w: Dlugossiana. Studia historyczne w pięćsetlecie śmierci Jana Dlugosza, red. S. Gawęda, Kraków 1980, s. 152-159; W. Drelicharz, Annalistyka małopolska, s. 80-85. O zespole ekspertów królewskich i jego działalności w latach 60. XV w. zob. P. Węcowski, Mazowsze w Koronie. Propaganda i legitymizacja władzy Kazimierza Jagiellończyka na Mazowszu, Kraków 2004, s. 284-286. 
(a wraz z nim inni członkowie delegacji) mieli dostęp do tego źródła jeszcze przed tą datą ${ }^{18}$. Wanda Semkowicz-Zarembina sądziła natomiast, że dostęp do Kroniki oliwskiej Długosz mógł uzyskać znacznie później, w latach 1465-1466 ${ }^{19}$. Jeśli tak było, to wówczas i mistrz Jan mógł napisać Sukcesję w tym czasie. W latach 60. XV w. z pewnością był już w Krakowie jakiś egzemplarz Kroniki oliwskiej, z którego korzystał Jan Długosz. Widać to na łamach Annales niejednokrotnie i z pewnością miał on dostęp do tej kroniki w Krakowie ${ }^{20}$.

Tak znaczne przesunięcie daty powstania Sukcesji wydaje się możliwe, ale mało prawdopodobne. Nie ma żadnych informacji źródłowych, aby po zakończeniu toruńskich negocjacji Jan Dąbrówka interesował się jeszcze sprawami polsko-krzyżackimi. Należy więc uznać, że Sukcesja najprawdopodobniej powstała jeszcze przed końcem lipca 1464 r. Można dopuścić jej napisanie po tym terminie, trudno sobie jednak wyobrazić, aby powstała po odzyskaniu Pomorza Gdańskiego przez Polskę. Jej treść ideowa (o której niżej) wyraźnie na to wskazuje. Terminus ante quem jej powstania to zatem zawarcie II pokoju toruńskiego. Podsumowując powyższe argumenty, można stwierdzić, że Sukcesja prawowitych dziedziców Pomorza musiała powstać między majem 1464 a październikiem 1466 r., najprawdopodobniej zaś jeszcze przed końcem lipca $1464 \mathrm{r}$.

Najwięcej informacji przy tworzeniu Sukcesji prawowitych dziedziców Pomorza Jan Dąbrówka zaczerpnął z Kroniki oliwskiej ${ }^{21}$. Utwór ten powstał w klasztorze cystersów w Oliwie w połowie XIV w. ${ }^{22}$ Jego początkowa część zawiera głównie informacje o dobrodziejstwach, jakie czynili klasztorowi książęta z dynastii Sobiesławiców, osnute na wiadomościach genealogicznych o tym rodzie. Dąbrówka wypreparował te właśnie dane i ułożył z nich drzewo genealogiczne potomków Sobiesława ${ }^{23}$. Stamtąd zaczerpnął też informację o uczynieniu księcia Przemysła dziedzicem Mściwoja II, roku śmierci tego ostatniego i miejscu pochówku, jak również o przyczynie śmierci Przemysła ${ }^{24}$. Jedyną informacją dotyczącą Sobiesławiców wziętą spoza Kroniki oliwskiej jest wzmianka o miejscu śmierci i pochówku Warcisława II. Dąbrówka zaczerpnął ją z Kroniki wielkopolskiej ${ }^{25}$, najpewniej z odpisu najłatwiej mu dostępnego, czyli znajdującego się w tym samym kodeksie co Sukcesja ${ }^{26}$.

18 S. Zonenberg, Źródła do dziejów Pomorza Gdańskiego, Prus i zakonu krzyżackiego w „Rocznikach” Jana Dlugosza (do 1299 roku), Toruń 2000, s. 46 n.

${ }^{19}$ W. Semkowicz-Zarembina, Powstanie i dzieje autografu Annalium Jana Dlugosza, RAU whf, t. 72, Kraków-Wrocław 1953, s. 56.

20 A. Semkowicz, Krytyczny rozbiór „Dziejów polskich” Jana Dlugosza (do roku 1384), Kraków 1887, s. 58-60; W. Polak, Aprobata i spór. Zakon krzyżacki jako instytucja kościelna w dziełach Jana Długosza, Lublin 1999, s. 113-116; J. Wenta, Dziejopisarstwo w klasztorze cysterskim w Oliwie na tle porównawczym, Gdańsk-Oliwa 1990, s. 23-25, 33-38 (o zachowanych do dziś rękopisach bliskich tym należącym do materiałów Długosza).

${ }^{21}$ Wyd.: Kronika oliwska, wyd. W. Kętrzyński, w: MPH, t. 6, Lwów 1893, s. 310-350. Istnieje również polskie thumaczenie tego utworu: Kronika oliwska. Źródło do dziejów Pomorza Wschodniego z połowy XIV wieku, tłum. D. Pietkiewicz, wstęp i koment. B. Śliwiński, Malbork 2008.

${ }^{22}$ Najbardziej szczegółowe opracowanie źródłoznawcze Kroniki oliwskiej zob. J. Wenta, Dziejopisarstwo w klasztorze cysterskim.

${ }^{23}$ Kronika oliwska, rozdz. 1, s. 310: ,primus monasterii Olyvensis fundator creditur fuisse Sobeslaus [...]. Hic post se reliquit duos filios Mistwugium et Zamborium”; tamże, rozdz. 1, s. 311: „Item filius eius [Zamborii] Sobeslaus [...]. Post mortem horum successit in ducatu Pomeranie dux Mistwugius, frater Zamborii [...]. Qui post se quatuor reliquit filios Swantopolcum, Samborium, Wardzlaum et Racziborium”; tamże, rozdz. 4, s. 313: „Iste [Swantopolcus] post se duos reliquit filios Mystvugium seniorem et Wardslaum iuniorem".

${ }^{24}$ Tamże, rozdz. 7, s. 315: „[I]deo tempore vite sue [Mystvugius] designavit sibi successorem dominum Primislium ducem Polonie [...]. Tandem defuncto Mystvugio anno Domini $\mathrm{M}^{\circ} \mathrm{CC}$.XCV VIII Kalendas Ianuarii et in Olyva sepulto [...]. Qui [Primislius] per satellites Woldemiri marchionis de Brandenburk occisus est in ulcionem sancte Lukardis coniugis sue, quam ipse male suspectam habens, fecerat iugulari”.

${ }^{25}$ Kronika wielkopolska, wyd. B. Kürbis, w: MPH s.n., t. 8, Warszawa 1970, rozdz. [161], s. 126: „Et cum [Warcislaus] castrum Wischegrod intravit, in egritudinem cadens mortuus est et sepultus in Juniori Wladislauia apud Fratres Minores”.

${ }^{26}$ Ustęp o śmierci i pogrzebie Warcisława znajduje się w Kodeksie Dąbrówki, k. 315r. Wątpliwość może wzbudzić fakt, że w tym kodeksie mamy wariant „,in Mynori Wladyslauia” (por. Kronika wielkopolska, rozdz. [161], s. 126, przyp. p), a w Sukcesji „,in Wladyslauia Iuniori” jak w niemal wszystkich pozostałych kodeksach. Poprawniejszy wariant nazwy miejscowości może być jednak łatwo wyjaśniony koniekturą Dąbrówki i nie należy na jego podstawie zakładać korzystania z innego rękopisu. 
Zagadnienie źródeł kolejnej części Sukcesji jest bardziej skomplikowane. Jak już wspomniałem, część tę traktowano dotąd jako osobny utwór mówiący o królach i książętach Polski. Jeśli jednak uznamy to twierdzenie za prawdziwe, staniemy przed zagadką: skąd Jan Dąbrówka zaczerpnął pomysł, by podać, że następcą Przemysła II był „Lestko dux Cuyawie”? I o jakiego władcę mogło mu chodzić? P. Węcowski uznał, że o Leszka Czarnego ${ }^{27}$, ten jednak nigdy nie panował na Kujawach, a żadne źródło nie podaje, aby był następcą Przemysła II (Leszek zmarł przecież ponad 7 lat przed Przemysłem). Jedyne możliwe wyjaśnienie jest następujące: nie chodzi o władców całej Polski, lecz nadal o Pomorze Gdańskie. Mistrz Jan podaje kolejnych władców Pomorza wymienianych przez Kronikę oliwską ${ }^{28}$. Wskazany w niej Leszek, książę Kujaw, to oczywiście nie Leszek Czarny, a Leszek inowrocławski, syn Siemomysła kujawskiego, który rzeczywiście opanował Gdańsk na krótki czas po śmierci Przemysła II.

W Kronice oliwskiej Dąbrówka przeczytał jednak tylko o jednym Przemyśle („,dominus Primislius dux"), a w Sukcesji umieścił dwóch: księcia Przemysła I i króla Polski Przemysła II, błędnie sądząc, że to pierwszemu z nich Mściwoj II przekazał prawa do Pomorza. Była to jego własna kombinacja historyczna, prawdopodobnie wynikająca z tego, że Przemysł został w Kronice oliwskiej nazwany właśnie $d u x$, a nie rex. Dąbrówka najpewniej ponownie sięgnął do dzieł historiograficznych z własnego kodeksu: z Kroniki wielkopolskiej wynikało, że Przemysł I zmarł jako książę ${ }^{29}$, a dzięki Rocznikowi kapituły poznańskiej wiedział o koronacji Przemysła II ${ }^{30}$. Mistrz Jan zignorował całkowicie chronologię, nie zwracając uwagę na datę śmierci Przemysła I, całkowicie wykluczającą ewentualność, aby mógł on dziedziczyć po Mściwoju II. Być może Dąbrówka zaufał zbytnio własnej pamięci? W rękopisie imię Przemysła I jest delikatnie przekreślone dwoma liniami, ledwo widocznymi z powodu jasnej barwy atramentu. Być może jest to ślad po próbie poprawienia błędu, jednak zarzuconej?

Władcy następujący w Sukcesji po Władysławie Łokietku to królowie polscy. Nie panowali oni nad Pomorzem i mistrz Jan doskonale o tym wiedział. Byli jednak dziedzicami Władysława Łokietka, a więc - co autor Sukcesji starał się udowodnić - tymi, którym przysługuje prawo do panowania na Pomorzu. Władców tych Jan Dąbrówka mógł wypisać po prostu z zakończenia swojego Komentarza do Kroniki polskiej mistrza Wincentego ${ }^{31}$, dodając do nich współczesnego sobie Kazimierza Jagiellończyka.

Treść ideowa Sukcesji prawowitych dziedziców Pomorza wpisuje się w długą tradycję polemik polsko-krzyżackich wokół kwestii Pomorza Gdańskiego. Już w 1312 r., podczas procesu przed delegatem papieskim Franciszkiem de Moliano, Krzyżacy przedstawiali swoją wersję przechodzenia tej ziemi z rąk do rąk. Według nich po bezpotomnej śmierci króla Czech, do którego należało Pomorze, przeszła ona w ręce króla Rzymian, który nadał ją margrabiemu brandenburskiemu. Krzyżacy świadomie zignorowali więc wcześniejsze panowanie na Pomorzu Sobiesławiców, a następnie Władysława Łokietka, a także fakt, że Wacław II władał tą ziemią jako król polski, a nie czeski ${ }^{32}$. Na kolejnym procesie, toczącym się między kwietniem 1320 a lutym 1321 r., obie strony powoływały się m.in. na argumenty nawiązujące do dziejów Pomorza. Krzyżacy tym razem nie pominęli Sobiesławiców milczeniem, stwierdzili jednak, że po śmierci Mściwoja II Pomorze przeszło w ręce króla czeskiego, a następnie margrabiego brandenburskiego i wreszcie zakonu. Świadkowie strony polskiej natomiast przypominali o panowaniu na Pomorzu po Mściwoju Przemysła II i Władysława Łokietka ${ }^{33}$. Także w XV w. pojawiały się podobnego

27 P. Węcowski, „Opera minora” Jana z Dąbrówki, s. 70.

${ }^{28}$ O Przemyśle zob. wyżej, przyp. 24. Kronika oliwska, rozdz. 7, s. 315: „Hoc [Premislio] ergo taliter sublato milites primo vocaverunt ducem Cuiavie Lestkonem”; tamże, rozdz. 8, s. 316: „Interea rex Bohemie Wenczeslaus secundus [...] ducatum Pomoranie obtinuit”; tamże, rozdz. 10, s. 317: „Cui [Wenczeslao] successit in regno filius eius Wenczeslaus IIIus”. Dąbrówka zignorował jednak podaną przez autora informację, że po Leszku, a przed Wacławem II mieszkańcy Pomorza mieli wezwać ,illum [ducem] de Rugia”; tamże, rozdz. 7 s. 315.

${ }^{29}$ Kronika wielkopolska, rozdz. [118], s. 107-109; Kodeks Dąbrówki, k. 308v-309r.

${ }^{30}$ Rocznik kapituły poznańskiej, nota [121], s. 53; Kodeks Dąbrówki, k. 317r.

31 Jan z Dąbrówki, Komentarz do Kroniki polskiej mistrza Wincentego zwanego Kadłubkiem, wyd. i wstęp M. Zwiercan, współpr. A.Z. Kozłowska, M. Rzepiela, w: MPH s.n., t. 14, Kraków 2008, s. 279; Kodeks Dąbrówki, k. 265v.

32 A. Wojtkowski, Tezy i argumenty polskie w sporach terytorialnych z Krzyżakami. Czesść pierwsza (1310-1454), „Komunikaty Mazursko-Warmińskie", 1966, nr 1, s. 9 n.

33 Tamże, s. 16-18. 
rodzaju argumenty w sporach polsko-krzyżackich. Memoriał biskupa krakowskiego Tomasza Strzępińskiego przygotowany na układy pokojowe z Krzyżakami, a wygłoszony w 1459 r. w Toruniu, wylicza 10 dokumentów dowodzących panowania na Pomorzu Mściwoja II, Przemysła II, Leszka inowrocławskiego, Wacława II i wreszcie Władysława Łokietka ${ }^{34}$.

$\mathrm{Na}$ tle tego długotrwałego sporu widać jasno intencje Jana Dąbrówki spisującego Sukcesję prawowitych dziedziców Pomorza. Pragnął on przede wszystkim pokazać ciągłość panowania Sobiesławiców na Pomorzu Gdańskim, a następnie podkreślić, że ostatni z tego rodu, umierając bezpotomnie, przekazał władzę (jak sądził) Przemysłowi I. Po nim rządzili kolejni przedstawiciele Piastów: Przemysł II i Leszek inowrocławski, następnie dwóch Wacławów, po których Pomorze Gdańskie wróciło do rąk Piastów w osobie Władysława Łokietka. I chociaż - jak Dąbrówka wiedział - Pomorze zostało Łokietkowi bezprawnie odebrane, prawa do tej ziemi przeszły na jego następców, królów Polski, z których obecnie panujący Kazimierz Jagiellończyk jest jedynym prawowitym panem tej ziemi. I właśnie ta konkluzja jest istotą treści ideowej Sukcesji.

W jakim celu powstała Sukcesja prawowitych dziedziców Pomorza? Biorąc pod uwagę jej lakoniczność, niewielkie rozmiary i skrótowość, można wykluczyć, aby mistrz Jan przeznaczył ją do szerszego rozpowszechniania. Miała raczej charakter notatki, pomocniczego szkicu lub też materiałów historycznych. Widzę dwie możliwości zastosowania tego typu pisma. Nie wykluczają się one, a przeciwnie, dopełniają. Mogła być to osobista notatka, zapisana z myślą o przygotowaniu większego dzieła, lub też szkic przygotowany dla polskich negocjatorów, aby na podstawie przedstawionej wiedzy formułowali argumenty za tym, że Pomorze Gdańskie należy się królowi polskiemu.

Jan Dąbrówka był już autorem podobnego typu szkicu, będącego w założeniu krótkim kompendium wiedzy historycznej dla polskich dyplomatów. Chodzi o trzecią redakcję Rodowodu ksiązą polskich. Jak wykazał P. Węcowski, powstała ona przed listopadem 1462 r. (a więc z pewnością przed Sukcesja). Jej celem było poinformowanie pozostałych członków delegacji królewskiej na zjazd w Piotrkowie o powiązaniach rodzinnych między zmarłymi właśnie książętami płockimi Siemowitem i Władysławem a pozostałymi gałęziami Piastów oraz o sposobach obierania władcy, zwłaszcza po bezpotomnej śmierci poprzednika. Dzięki temu można było przygotować argumenty za tym, że po zmarłych książętach powinien dziedziczyć król Polski, a także odrzucać twierdzenia innych Piastów mazowieckich, że rzekomo pochodzą od władców Rzymu ${ }^{35}$. Być może Jan Dąbrówka podobną rolę przeznaczył Sukcesji w związku z rokowaniami toruńskimi.

$\mathrm{Z}$ drugiej strony, warto wspomnieć o tym, że graficzne przedstawianie rozmaitych zagadnień dla własnego użytku było zwyczajem mistrza Jana, o czym świadczą rozmaite przykłady zachowane w zawierającym Sukcesję kodeksie. Najlepszym egzemplum są trzy redakcje wspomnianego Rodowodu książąt polskich, a zwłaszcza pierwsza, jako najbardziej osobista ${ }^{36}$. B. Kürbis zauważyła, że w rękopisie Kroniki wielkopolskiej w tym kodeksie znajdują się dwa schematy: jeden przedstawia podział ziem polskich między synów Krzywoustego, a drugi synów Mieszka Starego ${ }^{37}$. Liczne schematy, przedstawiające już nie genealogie, ale różne złożone pojęcia filozoficzne i prawne, znajdują się w tym kodeksie także w brulionie Komentarza do Kroniki polskiej mistrza Wincentego ${ }^{38}$. Takie analogie mogą świadczyć o osobistym charakterze Sukcesji.

Niezależnie od tego, które z zastosowań dla omawianego dziełka uznamy za pierwotne i najważniejsze, jest ono dla współczesnego badacza cennym źródłem przy odtwarzaniu warsztatu zarówno Jana Dąbrówki, jak i w ogóle XV-wiecznego historyka, a także zastosowania wiedzy historycznej w dyplomatycznych starciach między Polską a zakonem krzyżackim. Trzeba zauważyć, że Sukcesja nie jest banalnym i bezmyślnym wypisem opartym na jednym źródle. Czerpie ona z różnych źródeł i nie jest pozbawiona

\footnotetext{
${ }^{34}$ A. Wojtkowski, Tezy i argumenty polskie w sporach terytorialnych z Krzyżakami. Część druga (1454-1525), „Komunikaty Mazursko-Warmińskie”, 1967, nr 1-2, s. 20 n.

35 P. Węcowski, Mazowsze w Koronie, s. 208-212.

36 Tamże, s. 198-212; P. Węcowski, „Opera minora” Jana z Dąbrówki, s. 63-68.

37 B. Kürbis, Studia nad Kronika wielkopolską, s. 45; zob. też Kodeks Dąbrówki, k. 283r, 286r.

${ }^{38}$ Kodeks Dąbrówki, k. 77v, 103v, 105v, 134v, 140r, 144r.
} 
osobistej inwencji autora. Z pewnością nie jest najważniejszym dziełem w dorobku Jana Dąbrówki, ale - jak próbowałem pokazać - jest istotnym źródłem do badań nad warsztatem XV-wiecznego historyka, a także nad dyplomatycznymi sporami polsko-krzyżackimi. Mam nadzieję, że niniejszy artykuł stanie się impulsem do dalszych badań nad mniejszymi dziełkami Jana Dąbrówki oraz przygotowywania ich edycji krytycznych.

\section{Aneks}

\section{Wstęp}

Uznałem za stosowne, aby studium źródłoznawcze Sukcesji prawowitych dziedziców Pomorza zwieńczyć edycją krytyczną dzieła. Zabytek ten został już wydany drukiem przez B. Kürbis [dalej: edycja], jednak w sposób pobieżny i dalece niewystarczający. Wydanie w przypisie do innego utworu nie jest zadowalające w wypadku zabytku będącego ważnym źródłem do warsztatu Jana Dąbrówki i do dziejów historycznej argumentacji w sporach polsko-krzyżackich.

Podstawą wydania jest jedyny rękopis utworu zawarty w kodeksie Biblioteki Narodowej w Warszawie 3002 III na k. 316. W przypisach umieszczono warianty znajdujące się w edycji, aby rozwiać wątpliwości dotyczące odczytu.

Jan Dąbrówka często prezentował różne pojęcia i zależności (nie tylko genealogiczne lub historyczne) w formie graficznej. Dlatego też dołożyłem starań, aby jak najściślej oddać w edycji formę graficzną rękopisu. Pewne decyzje z tym związane mogą wydawać się kontrowersyjne. W rękopisie imiona synów Sobiesława I - Sambora I i Mściwoja I - zostały umieszczone w ten sposób, że Sambor I został mocno przesunięty w lewo. Może się wydawać, że Jan Dąbrówka umieścił tak Sambora ze względu na obawę przed brakiem miejsca na karcie, a więc oddawanie tego w wydaniu jest niepotrzebne, a synów Sobiesława należy pokazać równolegle, jak zrobiła to B. Kürbis. Być może jednak taki układ był świadomą intencją autora? Może mistrz Jan chciał pokazać w ten sposób, że (jego zdaniem) Sambor był znacznie starszy od Mściwoja i to dlatego ten drugi dziedziczył po swoim bratanku Sobiesławie (synu Sambora). Ze względu na tę możliwość pozostawiłem w wydaniu to przesunięcie. Aby zachować konsekwencję w oddawaniu układu graficznego, również notkę o przyczynach śmierci Przemysła II umieściłem tam, gdzie znalazła się ona w rękopisie, chociaż najpewniej została tam umieszczona ze względu na brak miejsca przy notce o Mściwoju II, której jest kontynuacją.

Koniecznie jest również wyjaśnienie wyglądu linii łączących poszczególne osoby. Zostały one bowiem pomyślane tak, aby oddawały charakter linii zawartych w rękopisie. W części dotyczącej dynastii Sobiesławiców są to najczęściej klamry obejmujące określone osoby, po to, aby uwidocznić ich pochodzenie. W następnej części natomiast są to przedłużenia ostatnich liter w ostatnim wyrazie notki, ciągnące się aż do pierwszego wyrazu następnej notki.

W edycji zrezygnowałem z interpunkcji oraz wielkich liter na początku zdania, za wyjątkiem passusu o przyczynach śmierci Przemysła II.

Przy tworzeniu przypisów rzeczowych dotyczących osób korzystałem z biogramów zawartych w PSB. Osoby niemające haseł w tym słowniku objaśniłem z pomocą prac genealogicznych dotyczących Sobiesławiców, Piastów, Przemyślidów i Jagiellonów. W wypadku nazw miejscowych podałem współczesną przynależność administracyjną.

We wszystkich sprawach tu niewzmiankowanych przestrzegałem instrukcji wydawniczej Adama Wolffa ${ }^{39}$.

39 A. Wolff, Projekt instrukcji wydawniczej dla pisanych źródeł historycznych do połowy XVI wieku, St. Źrodł., 1, 1957, s. $155-181$. 


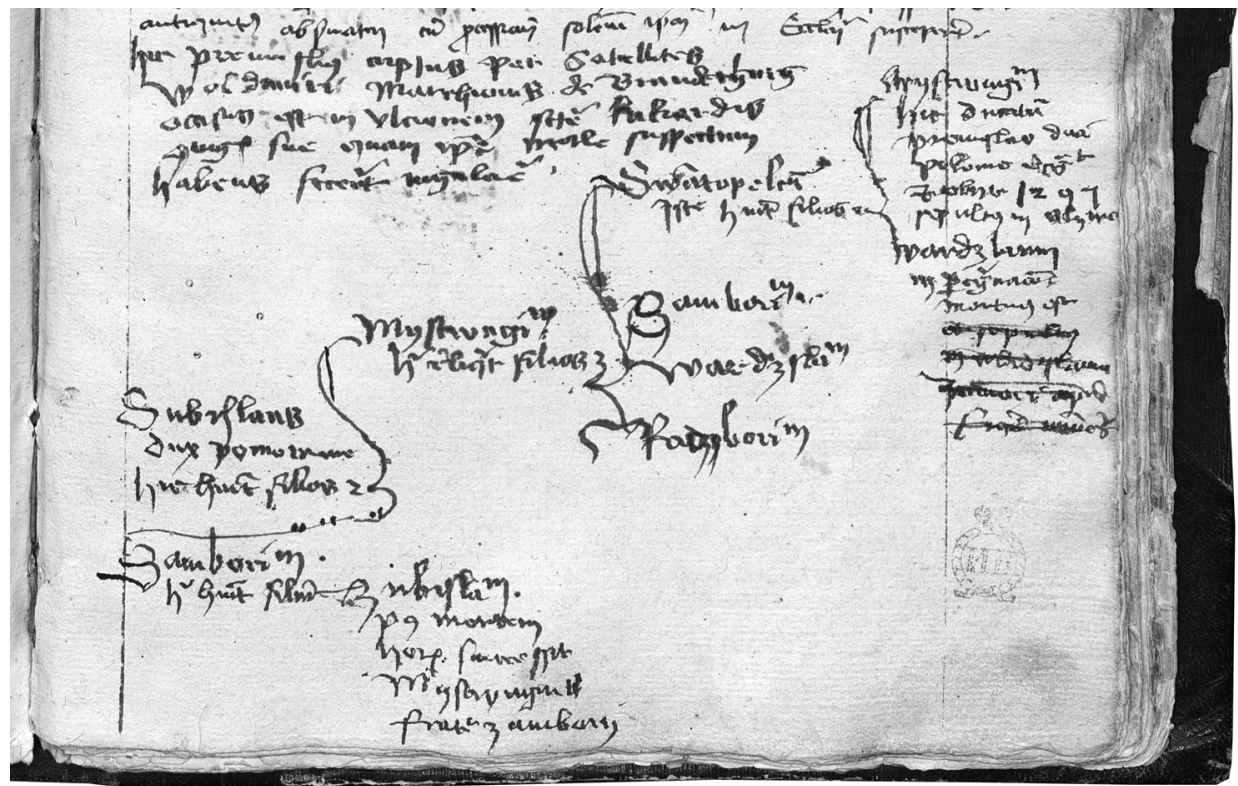

Il. 1. BN, rkps 3002 III, dolna część k. 316r

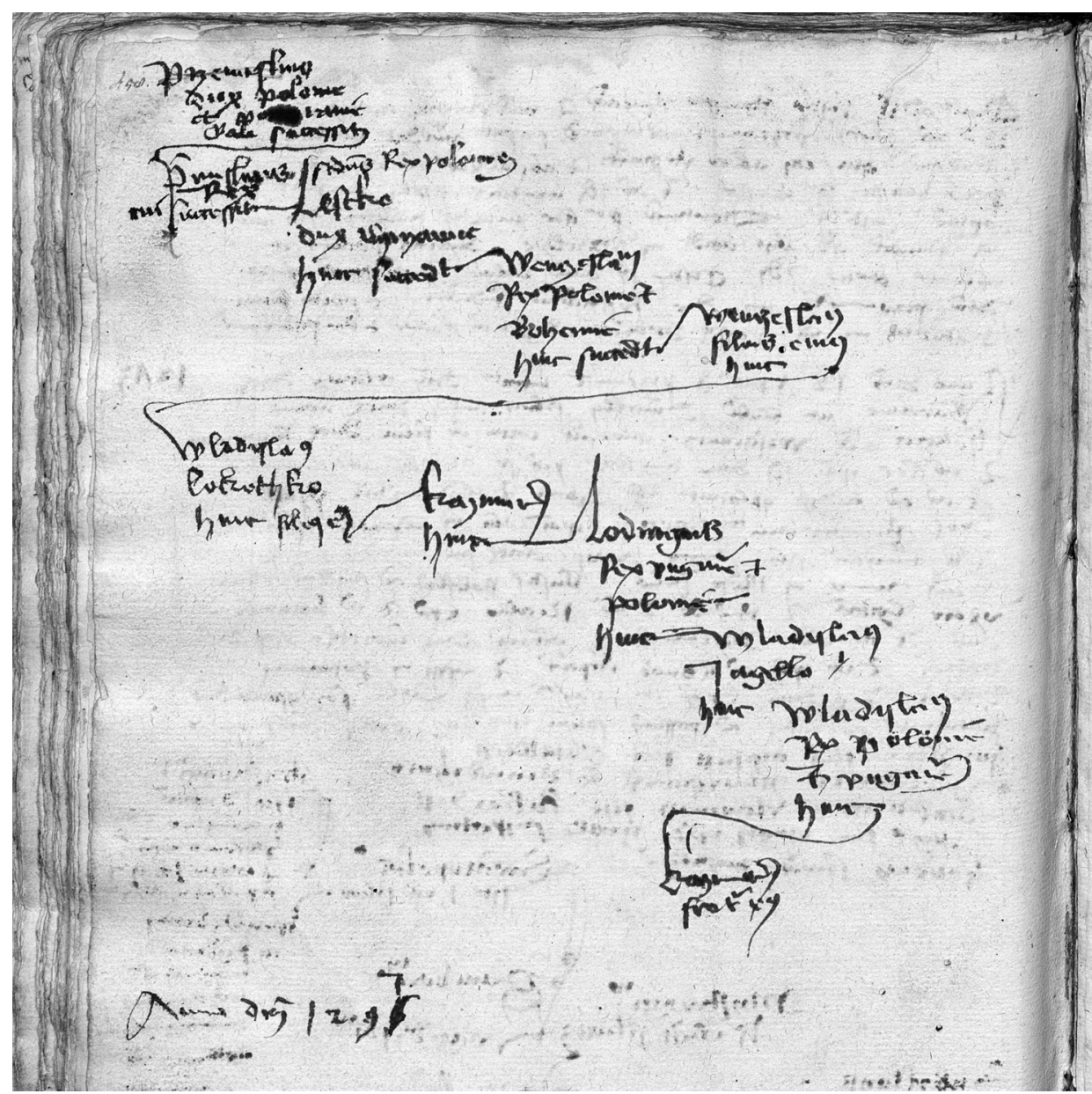

Il. 2. BN, rkps 3002 III, górna część k. 316v 


\section{Sukcesja prawowitych dziedziców Pomorza [Successio legitimorum heredum Pomeraniae]}

\section{[k. 316r]}

Hic Premislius captus per satellites Woldimirif marchonis de Brandenburg occisus est in ulcionem sancte Lukardis ${ }^{13}$ Mystwugium $^{9}$ coniugis sue quam ipse male susceptam habens fecerat iugulare.

hic ducatum

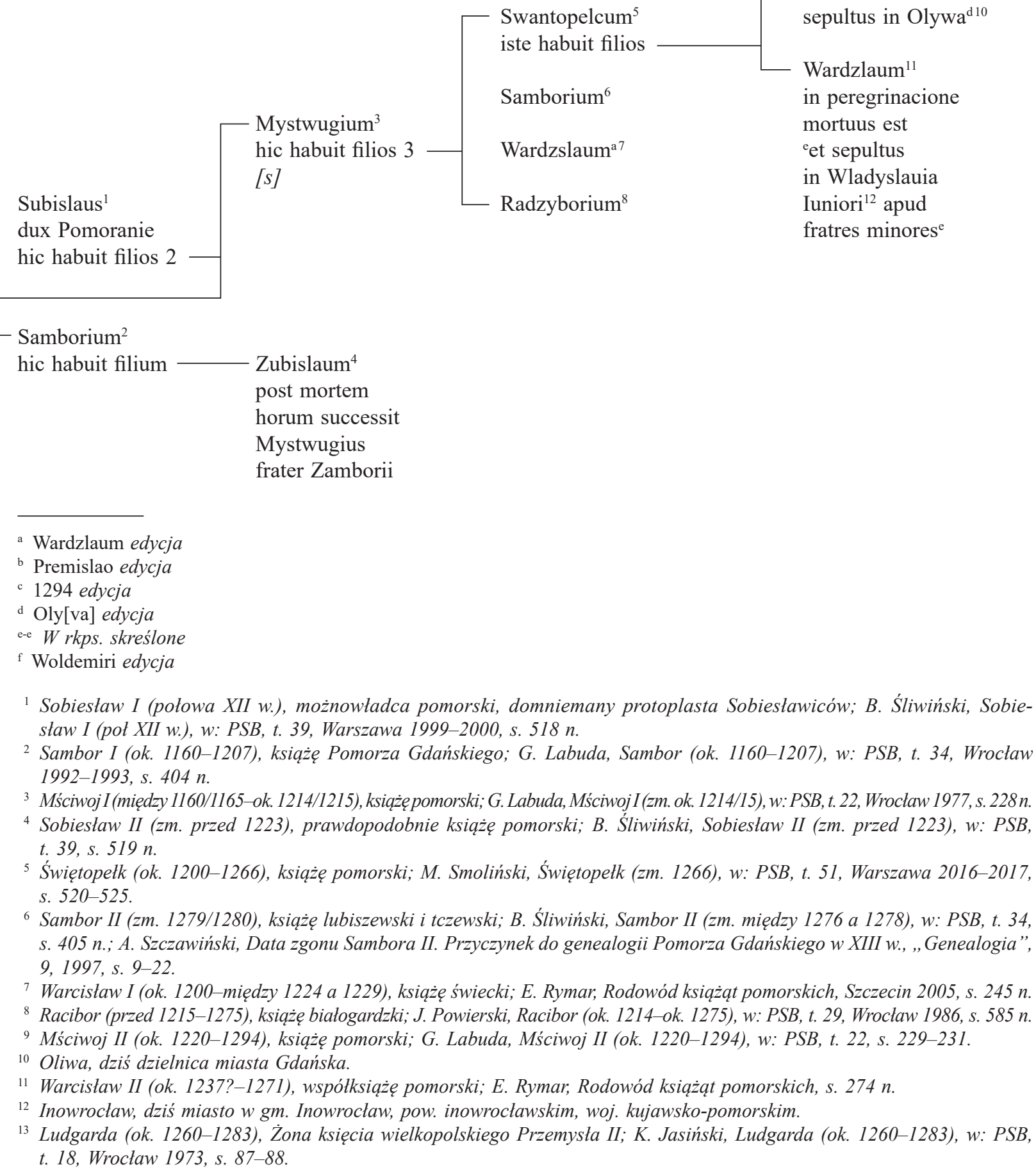

- Swantopelcum ${ }^{5}$ iste habuit filios Samborium $^{6}$ ystwugium ${ }^{3}$ hic habuit filios 3 $[s]$ Wardzslaum $^{\mathrm{a} 7}$ Radzyborium $^{8}$ sepultus in Olywa ${ }^{\mathrm{d} 10}$

Wardzlaum $^{11}$ in peregrinacione mortuus est eet sepultus in Wladyslauia Iuniori ${ }^{12}$ apud fratres minores ${ }^{\mathrm{e}}$

- Samborium ${ }^{2}$ hic habuit filium

Zubislaum ${ }^{4}$ post mortem horum successit Mystwugius frater Zamborii

\footnotetext{
${ }^{a}$ Wardzlaum edycja

b Premislao edycja

c 1294 edycja

d Oly[va] edycja

e-e W rkps. skreślone

${ }^{\mathrm{f}}$ Woldemiri edycja
}

${ }^{1}$ Sobiestaw I (polowa XII w.), możnowładca pomorski, domniemany protoplasta Sobiestawiców; B. Śliwiński, Sobiestaw I (pot XII w.), w: PSB, t. 39, Warszawa 1999-2000, s. 518 n.

2 Sambor I (ok. 1160-1207), ksiaże Pomorza Gdańskiego; G. Labuda, Sambor (ok. 1160-1207), w: PSB, t. 34, Wroctaw 1992-1993, s. 404 n.

${ }^{3}$ Mściwoj I (między 1160/1165-ok. 1214/1215), ksiązępomorski; G. Labuda, Mściwoj I(zm. ok. 1214/15), w: PSB, t.22, Wrockaw 1977, s. 228n.

${ }^{4}$ Sobiestaw II (zm. przed 1223), prawdopodobnie ksiaże pomorski; B. Śliwiński, Sobiestaw II (zm. przed 1223), w: PSB, t. 39 , s. 519 n.

${ }^{5}$ Świętopetk (ok. 1200-1266), książę pomorski; M. Smoliński, Świętopetk (zm. 1266), w: PSB, t. 51, Warszawa 2016-2017, s. $520-525$.

${ }^{6}$ Sambor II (zm. 1279/1280), ksiażę lubiszewski i tczewski; B. Śliwiński, Sambor II (zm. między 1276 a 1278), w: PSB, t. 34, s. 405 n.; A. Szczawiński, Data zgonu Sambora II. Przyczynek do genealogii Pomorza Gdańskiego w XIII w., „Genealogia”, 9, 1997, s. 9-22.

7 Warcistaw I (ok. 1200-między 1224 a 1229), ksiażę świecki; E. Rymar, Rodowód ksiażat pomorskich, Szczecin 2005, s. 245 n.

${ }^{8}$ Racibor (przed 1215-1275), ksiaże biatogardzki; J. Powierski, Racibor (ok. 1214-ok. 1275), w: PSB, t. 29, Wrocław 1986, s. 585 n.

${ }^{9}$ Mściwoj II (ok. 1220-1294), ksiaże pomorski; G. Labuda, Mściwoj II (ok. 1220-1294), w: PSB, t. 22, s. 229-231.

${ }_{10}$ Oliwa, dziś dzielnica miasta Gdańska.

${ }^{11}$ Warcistaw II (ok. 1237?-1271), wspótksiąze pomorski; E. Rymar, Rodowód ksiażat pomorskich, s. 274 n.

${ }^{12}$ Inowrocław, dziś miasto $w$ gm. Inowrocław, pow. inowrocławskim, woj. kujawsko-pomorskim.

${ }^{13}$ Ludgarda (ok. 1260-1283), Żona księcia wielkopolskiego Przemysta II; K. Jasiński, Ludgarda (ok. 1260-1283), w: PSB, t. 18, Wroctaw 1973, s. 87-88.

Premyslao $^{b}$ duci Polonie dedit et obiit $1295^{\circ}$ 
[k. 316v]

Przemislius $^{\mathrm{g} 14}$

dux Polonie

et $\mathrm{P}[$ ome $]$ ranie $^{\text {h }}$

cui successit $\longrightarrow$

Premislius secundus ${ }^{15}<$ rex Polonie $>^{\mathrm{i}}$
rex $[s]$
$\begin{array}{ll}\text { cui successit } & \text { Lestko }^{16} \\ & \text { dux Cuyawie } \\ & \text { huic succedit }\end{array}$

huic succedit Wenczeslaum ${ }^{\mathrm{j} 17}[s]$

rex Polonie et

Bohemie Wenczeslaus $^{18}$

huic succedit filius eius

huic

Wladyslaus $^{\mathrm{k}}$

Lokethko

huic filius eius

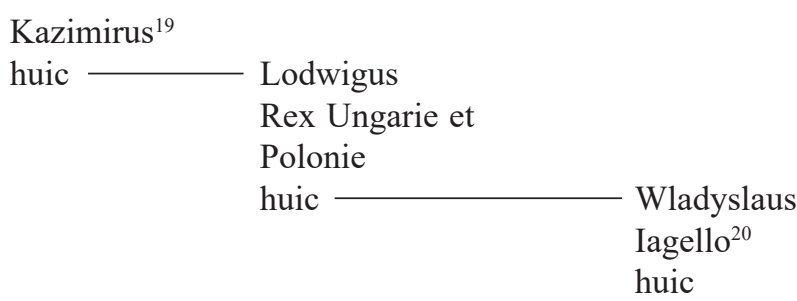

Wladyslaus $^{21}$

Rex Polonie

et Ungarie

huic

$<\begin{gathered}\text { Cazimirus }^{22} \\ \text { frater eius }\end{gathered}$

g W rkps. wyraz przekreślony

h W rkps. wyraz częściowo zakryty przez plamę atramentu

i W rkps. późniejszy dopisek ta sama ręka

j Wenczeslaus edycja

k Wladislaus edycja

14 Przemyst I (1220/1221-1257), książę wielkopolski; K. Jasiński, Przemyst I (1220/1-1257), w: PSB, t. 28, Wrocław 1984-1985, s. $728-730$

15 Przemyst II (1257-1296), książe wielkopolski, krakowski, pomorski, król polski; tenże, Przemyst II (1257-1296), w: PSB, t. 28, s. 730-733.

${ }^{16}$ Leszek inowrocławski (ok. 1275-ok. 1340), książe inowrocławski, pomorski; tenże, Leszek (ok. 1275-ok. 1340), w: PSB, t. 17, Wroctaw 1972, s. 160 n.

17 Wacław II (1271-1305), król czeski i polski; J. Szymczak, Genealogia Przemyślidów z przełomu XIII i XIV wieku spokrewnionych z Piastami, „Acta Universitatis Nicolai Copernici. Historia”, 8, 1973, s. 42.

18 Wactaw III (1289-1306), król węgierski i czeski, pretendent do tronu polskiego; tamże, s. 43-45.

19 Kazimierz Wielki (1310-1370), król polski; Z. Kaczmarczyk, Kazimierz Wielki (1310-1370), w: PSB, t. 12, Wrocław 1966-1967, s. 264-269.

${ }^{20}$ Władysław Jagiełto (po 1350-1434), wielki książę litewski, najwyższy książę litewski, król polski; J. Tęgowski, Pierwsze pokolenia Giedyminowiczów, Poznań-Wrocław 1999, s. 124-131.

21 Władysław Jagiellończyk (1424-1444), król polski; tamże, s. 136-138.

${ }^{22}$ Kazimierz Jagiellończyk (1427-1492), wielki książę litewski, król polski; S.M. Kuczyński, Kazimierz Andrzej Jagiellończyk (1427-1492), w: PSB, t. 12, s. 269-274. 


\section{The Succession of Rightful Heirs of Pomerania by Jan Dąbrówka. A source study and critical edition}

Summary: The article presents a source study and critical edition of a short text by Jan Dąbrówka, for which the following title is proposed: The Succession of Rightful Heirs of Pomerania. In the earlier literature, it was regarded as two separate pieces, entitled Genealogia ksiażat pomorskich (Genealogy of Pomeranian Princes) and Poczet ksiązą $i$ królów polskich (Gallery of Princes and Kings of Poland). After the description of previous references to the text, the article's author discusses the only manuscript of the work: the codex of the National Library in Warsaw no. 3002 III (known as Jan [of] Dąbrówka's Manuscript or Manuscript of Lubiń). Next, he goes to the question of its author, supporting the opinion that the authorship of The Succession should be ascribed to Jan Dąbrówka. Further on, he discusses the time of its writing, estimated to be the period between the early May 1464 and October 1466. The most probable seems to be the period between May and July 1464. Then, he examines the sources on which The Succession was based: first and foremost, the Oliva Chronicle and the Commentary to the Chronicle by Master Vincent, and, to a lesser extent, the Greater Poland Chronicle. The following part presents the description of the ideological content of The Succession - it was to prove the rights of Casimir IV Jagiellon to Gdańsk Pomerania - and its purpose: it was a personal note, methodological assistance, a sketch for a more comprehensive work, or brief historical materials for Polish diplomats.

Nota o autorze: Michał Kulpa, ur. 1992, absolwent Instytutu Historii Uniwersytetu Jagiellońskiego, obecnie doktorant na Wydziale Historycznym tegoż uniwersytetu. Pod kierunkiem dr. hab. Wojciecha Drelicharza, prof. UJ, przygotowuje pracę doktorską na temat późnej polskiej hagiografii św. Wojciecha. Jego zainteresowania badawcze koncentrują się wokół średniowiecznej polskiej historiografii i hagiografii, paleografii łacińskiej, kodykologii oraz języka łacińskiego.

Author: Michał Kulpa, b. 1992, graduate of the Institute of History of Jagiellonian University in Cracow, presently PhD student at the Faculty of History of Jagiellonian University. He prepares his thesis on late Polish lives and passions of St Adalbert (Wojciech) under the direction of Wojciech Drelicharz. His research interests include Polish medieval historiography and hagiography, Latin palaeography, codicology, and Latin language.

e-mail: michal.kulpa@student.uj.edu.pl

\section{Bibliografia}

\section{Źródla drukowane}

Hanserecesse von 1431-1476, t. 1-7, wyd. G. von der Ropp, Leipzig 1876-1892

Jan z Dąbrówki, Komentarz do Kroniki polskiej mistrza Wincentego zwanego Kadtubkiem, wyd. i wstęp M. Zwiercan, współpr. A.Z. Kozłowska, M. Rzepiela, w: MPH s.n., t. 14, Kraków 2008

Kronika oliwska, wyd. W. Kętrzyński, w: MPH, t. 6, Lwów 1893, s. 310-350

Roczniki wielkopolskie, wyd. B. Kürbis, współudz. G. Labuda, J. Luciński, R. Walczak, w: MPH s.n., t. 6, Warszawa 1962

\section{Opracowania}

Biskup M., Dziatalność dyplomatyczna Jana Dlugosza w sprawach pruskich w latach 1454-1466, w: Dlugossiana. Studia historyczne w pięćsetlecie śmierci Jana Dlugosza, red. S. Gawęda, Kraków 1980, s. 141-167

Biskup M., Trzynastoletnia wojna z Zakonem Krzyżackim 1454-1466, Olsztyn 2014

Drelicharz W., Annalistyka małopolska XIII-XV wieku. Kierunki rozwoju wielkich roczników kompilowanych, RAU whf, t. 99, Kraków 2003

Inwentarz rękopisów do połowy XVI wieku w zbiorach Biblioteki Narodowej, oprac. J. Kaliszuk, S. Szyller, Inwentarze Rękopisów Biblioteki Narodowej, t. 3, Warszawa 2012

Polak W., Aprobata i spór. Zakon krzyżacki jako instytucja kościelna w dziełach Jana Dtugosza, Lublin 1999

Semkowicz-Zarembina W., Powstanie i dzieje autografu Annalium Jana Dlugosza, RAU whf, t. 72, Kraków-Wrocław 1953

Wenta J., Dziejopisarstwo w klasztorze cysterskim w Oliwie na tle porównawczym, Gdańsk-Oliwa 1990 
Węcowski P., Mazowsze w Koronie. Propaganda i legitymizacja władzy Kazimierza Jagiellończyka na Mazowszu, Kraków 2004

Węcowski P., „Opera minora” Jana z Dąbrówki, w: Komentarz Jana z Dąbrówki do Kroniki biskupa Wincentego, red. A. Dąbrówka, M. Olszewski, Studia staropolskie. Series Nova, t. 42 (98), Warszawa 2015, s. 58-75 Wojtkowski A., Tezy i argumenty polskie w sporach terytorialnych z Krzyżakami. Czesść pierwsza (1310-1454), „Komunikaty Mazursko-Warmińskie”, 1966, nr 1, s. 3-98

Wojtkowski A., Tezy i argumenty polskie w sporach terytorialnych z Krzyżakami. Część druga (1454-1525), „Komunikaty Mazursko-Warmińskie”, 1967, nr 1-2, s. 3-84

Zonenberg S., Źródła do dziejów Pomorza Gdańskiego, Prus i zakonu krzyżackiego w „Rocznikach” Jana Dtugosza (do 1299 roku), Toruń 2000

Zwiercan M., Komentarz Jana z Dąbrówki do Kroniki mistrza Wincentego zwanego Kadłubkiem, Wrocław 1969 